\title{
Solar PV: Investigating The Gap In Renewable Energy Policy Formulation And Implementation In Nigeria
}

\author{
Chinedu Okoye \\ BA Hons (Coventry), MSc (Warwick) \\ Research Directorate, National Institute for Policy and Strategic Studies, \\ Kuru, Jos, Plateau State. Nigeria.
}

\begin{abstract}
This paper identifies a gap in, or between, the formulation and implementation of Renewable Energy (RE) policies in Nigeria. This gap, the paper submits, is the major factor behind the comparative lack of seeming progress in terms of societal appreciation/patronage, installation of Renewable Energy facilities and technology, acquisition of the required know-how for their maintenance and operation, poor RE energy/power generation, evacuation and distribution to the targeted end users. In making and backing up this submission, the paper evaluates key preliminary issues, the primary causative factors. Additionally, the paper runs an issue/comparative analysis. On the issue of societal apathy and lack of awareness, the paper carries out a survey directed at randomly picked citizens, in which their understanding, appreciation and willingness to patronise Renewable Energy is assessed. The paper, makes strategic recommendations that are practical and specific, and which if taken into consideration by concerned stakeholders especially the Government, at the policy formulation and implementation stages, will go a long way to bridging these gaps while ensuring a healthy energy mix for the benefit of the Country, and the attainment of the Vision 30:30:30.
\end{abstract}

\section{INTRODUCTION/PROBLEM DEFINITION}

The Federal Government of Nigeria under the '30:30:30 Electricity Vision', unfolded a blueprint aimed at generating an ambitious 30 Giga Watts (30000 Mega Watts) of on-grid electric power capacity, a target it intended to achieve by the year 2030 . Thirty percent (30\%) of the total capacity is to be generated through renewable energy. This plan was internationally amplified further by President Muhammadu Buhari on the sidelines of the 2016 United Nations Climate Change Conference, held in Marrakech, Morocco. He was represented by the then Environment Minister, Amina Mohammed, at the African Union hosted, side event, which was (not) surprisingly, themed: "Moving from Commitment to Action with the Intended Nationally Determined Contribution (NDC) and the African Renewable Energy Initiative (AREI)". The 2016 event theme title itself, indicates an identified lack of practical action on the part of African Governments in implementing renewable energy policies, hence the attempt at influencing a reawakening via the event.

The President, in his speech, highlighted the Sustainable Energy for All Action Agenda and the National Renewable Energy Action Plan (NREAP) as prominent aspects of the Vision 30:30:30, deliberately designed towards increasing the National on-grid capacity from the current dismal 5 Giga Watts, to 30 Giga Watts by the year 2030.

Despite the commendable intentions of the Government, there is comparatively little on ground to indicate commencement of such an ambitious initiative especially with specific regards to renewable energy which is the focus of this report. At the current rate, Vision 
30:30:30, if not properly managed, owned, marketed to stakeholders and implemented, risks ending up like its predecessors i.e. Vision 2010 and Vision 20:20:20.

This paper attempts at evaluating the 'why', despite steps taken by the Government to formulate policies and regulatory frameworks, there is still a large gap when it comes to implementation, project roll out, and the targeted power service delivery.

This paper comes up with a hypothesis, that identifies lack of enabling structures, manpower and technical resources on the part of the Nigerian Government as a major causative factor for this gap, this gap represents the inability of Government to carry its initiative/policies through to implementation. Apathy on the part of Government is also a major factor, driven by over reliance on fossil fuel, and what is perceived to be the strategic economic proceeds it earns for the country. As a result, and among other things, there is the resultant reluctance to diversify away from fossil fuel. Apathy on the part of citizens/stakeholders is due to lack of awareness a seeming lack of knowledge, appreciation and understanding of the concept, its technology, its actual benefits, and a preponderant ignorance of the breakthrough that is Renewable Energy. Research suggests, the public will resist the adoption of new technologies due to the lack of information about the products and their functionalities, (Wixom \& Todd, 2005).

This paper, focuses on Solar Renewable Energy (RE) considering its highly abundant sources (in Nigeria), and the comparatively low technical knowhow required to build, operate and maintain it technological resources, especially when placed side by side with the cumbersome and complex likes of Wind, Biomass, Geothermal etc. Additionally, this report identifies Solar $\mathrm{RE}$ as the major plank of the Nigerian Governments Renewable Energy Policy.

Solar Photo-Voltaic entails the conversion of solar energy or sunlight directly into electricity with the aid of PV panels - which comprise thin films mostly made of crystalline silicon, and organic compounds like dye-sensitized cells, (Amankwah-Amoah, 2014, Wu \& Mathews, 2012).

This paper will through its issue analysis, proposed solutions and strategic recommendations; create the awareness needed by the Government to better appreciate the Solar PV potential, evaluate the inputs needed to guide the holistic implementation of Solar PV and its delivery performance respectively, and finally, come up with solutions and recommendations that if implemented will potentially ensure the attainment of the 2030 target. There is need on the part of Government to accept that drafted policies, vision blueprints and regulatory frameworks - although commendable - are not enough, there are certain practical pre-requisite steps that will have to be taken to complement the drive for this target to be achieved.

\section{ISSUE ANALYSIS/REVIEW}

Solar - Renewable Energy is the most viable of the renewable alternatives in the Nigerian socio-economic, geographical and technological context. With Nigeria geographically located on a high solar radiation belt, the Country is abundant in solar resources with an average solar irradiation of $2011 \mathrm{kWh} / \mathrm{m} 2$ per year, (Coker, 2017). Northern Nigeria compares to Southern Nigeria at $7 \mathrm{KWh} / \mathrm{m} 2$ to $4 \mathrm{KWh} / \mathrm{m} 2$ respectively in terms of horizontal solar irradiation. Experts estimate that solar PV panels strategically placed on just $1 \%$ of Northern Nigeria land area has the potential to harness and produce 207,000 GWh of electric power per year, which according to Heinrich Boll Stiftung, Nigeria, is equivalent to about 4.6 million barrels of oil per day. 
In the technological context, and as an advantage, Solar PV requires comparatively less technological input, manpower and resources compared to those of Wind, Biomass etc, this favors Nigeria as an emerging and developing economy not yet deeply rooted in infrastructural technology.

Successive Nigerian Governments have taken certain steps towards creating a seeming investor friendly environment that would ultimately support investment and growth in the solar - renewable sector. In 2010, under the administration of President Goodluck Jonathan, the drive for the implementation of the Electric Power Sector Reform Act was boosted with the establishment of the 800 million dollar capitalized Nigerian Bulk Electricity Trading. The NBET was charged with the responsibility of buying and selling power from Independent Power Purchasers and selling same to distribution companies. There was a commitment to buy a sizeable percentage of that power from renewable sources most especially solar.

In 2012, under the same administration, the Nigerian Electricity Regulatory Commission introduced the Re FIT program i.e. the Renewable Energy Feed in Tariff, to streamline negotiation bottlenecks, and guarantee easier access to grids from or for solar energy sources. The Re FIT program came with an inclusive obligation of the Federal Government to purchase $50 \%$ of it electric power requirement from renewable energy sources.

In 2015, power generating companies were incentivized through a Government Power Production Tax Credit which included a five year tax holiday for renewable energy investors and manufacturers. Zero percent custom duty was to be granted to importers bringing in renewable energy resources, materials and equipment for a period of two years.

The Vision 30:30:30 initiative by the current Government of President Buhari has so far been able to attract power developers both local and foreign. Combined, 14 of them have committed to adding 1200 Mega Watts to the grid as seen from the table below:

\begin{tabular}{|l|c|c|}
\hline \multicolumn{1}{|c|}{ Company } & Megawatts (MW) & State \\
\hline Access Power (Quaint Abiba Solar Project) & $50 \mathrm{MW}$ & Kaduna \\
\hline Afrinergia Power & $50 \mathrm{MW}$ & Nasarawa \\
\hline Anjeed Innova & $10 \mathrm{MW}$ & Kaduna \\
\hline CT Cosmos & $70 \mathrm{MW}$ & Plateau \\
\hline En Africa & $50 \mathrm{MW}$ & Kaduna \\
\hline $\begin{array}{l}\text { GreenWish Partners. } \\
\text { *partnered with Motir DuSable (Enugu) } \\
\text { and Oriental Renewable Solution (Jigawa) }\end{array}$ & $\begin{array}{c}100 \mathrm{MW} \\
50 \mathrm{MW}\end{array}$ & $\begin{array}{c}\text { Enugu } \\
\text { Kaduna } \\
\text { Jigawa }\end{array}$ \\
\hline Kvk Powers & $50 \mathrm{MW}$ & Sokoto \\
\hline LR Aaron Power & $100 \mathrm{MW}$ & *FCT - Abuja \\
\hline Nova Scotia Power Development & $80 \mathrm{MW}$ & Jigawa \\
\hline Pan Africa Solar \& JCM Power & $75 \mathrm{MW}$ & Katsina \\
\hline Middle Band Solar One & $100 \mathrm{MW}$ & Kogi \\
\hline Motir DuSable & $100 \mathrm{MW}$ & Nasarawa \\
\hline Nigerian Solar Capital Partners & $100 \mathrm{MW}$ & Bauchi \\
\hline Nova Solar 5 & $100 \mathrm{MW}$ & Katsina \\
\hline
\end{tabular}

Figure 1: '14 Signed Power Purchase Agreements.. expected to add 1200MW of Solar capacity to the grid' - (Coker, 2017) 
According to Coker, 2017, reasonable progress has been recorded in the Nigeria renewable energy regulatory framework, and as a result, investments adding up to 1.76 billion US dollars has been attracted into the energy sector/economy.

However, what should be the attendant results on ground in terms of facilities, structures, and most importantly increased power generated and distributed from solar does not match or complement the renewable energy policy initiatives reported above.

Preliminary investigations into the activities of the 14 Power developers in Figure 1 above indicate they are currently not generating close to the respective capacities they committed to in 2016. With such performance among a variety of other drawbacks, Governments commitment to generating 30 percent of the overall $30 \mathrm{GW}$ target from Renewable, which is 9 GW i.e. 9,000 MW remains a tall order.

"We are experiencing a solar revolution in Chile, and this is the result of the policies that we have implemented in the last three years"

- Chile Energy Minister, Andre's Rebolledo

The above statement by the Chilean Energy Minister, underscores this reports primary submission that the gap in Nigeria's Solar Energy policy initiatives and the lack of commensurate progress on ground lies in implementation - the how best to. Successful implementation can only take place if the necessary foundation is laid for a well balanced holistic take off and sustenance, (Zhang \& Yongxiu,2013).

As an integral part of implementation efforts, the Government must communicate its policy to the people in the form of sensitizations, seminars, outreaches and inclusive conferences. Countries like Germany, United States and the United Kingdom have made far reaching progress in their respective renewable energy journeys, especially Solar PV. Industry experts attribute these successes to communicating, educating and creating a massive awareness in their respective Countries, hence compelling citizens and other stakeholders to buy into and support the initiative through their patronage, (IRENA, 2017). A large number of Nigerians are still unaware of what actually is renewable energy, how it works and how it stands to benefit them in a way that is beneficial to them, clean and not harmful to the environment. For them to buy into RE and the drive for Vision 30:30:30, awareness around RE has to be created and knowledge around the Vision/Policy has to be communicated. Designing a Vision policy or plan without communicating the issues with stakeholders like youths, activists, civil societies, media, trade unions, academia, rural communities, not for profits and potential investors - will make complementary cooperation and ownership difficult as the knowledge and understanding needed to appreciate and key-in is absent.

Financial security is provided by Governments in Countries like South Africa and Kenya as a means of incentivizing those willing to invest in Solar RE, which at the onset is high risk, capital intensive, with high return on investment (ROI) uncertainty. This model can be borrowed by Nigeria. Lending institutions like banks are normally reluctant to give out loans to renewable project developers/investors, because of the anticipated uncertainty in ROI. Government can provide financial securities, in the form of loans, credit facilities, equities; to help mitigate risks both for the banks and developers, (Zhang \& Yongxiu,2013).

East African Countries like Tanzania and Rwanda, engender community partnerships and active participation in establishing Solar - Renewable Energy projects and this has had a tremendous impact on 'on and off grid' implementation efforts in these two Countries. This is a 
model that can be applied in the Nigerian context, it will enable management and operational structures whereby communities can take ownerships of these facilities, which guarantees its security and protection from thieves and vandals, and allows for a more streamlined maintenance of the facilities while at the same time acquiring the informal technical and operational know-how , (The Beam, 2016).

China's success story in renewable energy is mainly driven by its highly skilled solar work force, today China is at the forefront of Solar PV panels manufacturing, custom fabrication, installation, engineering and export. The Country's commitment to reducing its Carbon emissions majorly via souring manufacturing/industrial pollutions meant opting for cleaner alternatives of energy hence the aggressive push for renewables, (Osborne, 2017). To achieve this, China has among other things, designed a technical curriculum that would go on to urgently train a new generation of workforce skilled enough to lead the world in Solar PV manufacture and engineering, (IEEFA, 2017).

The Nigerian Government should commence immediate curriculum design at University/Polytechnic/College level that will provide for training, skill acquisitions, technical competency development and advocacy needed for acquiring Solar RE industry-compliant skills. Some of the skills currently lacking in the Country today, are Solar PV Designers, Solar Project/Installation Engineers, Solar Operations and Maintenance Engineers. To build on sustainability and growth, there is need to move away from over reliance on foreign labour and imports.

As earlier highlighted, there is an alarming rate of apathy within Government circles with regard to the viability and potential that is Renewable Energy. Government should focus on educating its own personnel and stakeholders to get them to fully buy into the Renewable Energy policy. In 2015, the Director-General of National Power Training Institute of Nigeria (NAPTIN), dismissed the prospects of Renewable Energy in Nigeria, saying the Country is not ripe for it, the economy he said cannot be powered satisfactorily using renewable energy sources, he recommended that the Government sticks to fossil fuels. The Managing Director of Ikeja Electric speaking to the media, also opposed the Renewable Energy idea arguing that they can only provide insignificant quantum of electric megawatts which cannot meet the need of the Country and its citizens, (The Nation, 2015). There is need for such wrong narrative to be countered with superior, research backed information. Olaoye et al (2016), in their paper, submit that solar energy is abundant in all parts of Nigeria at an average sunshine of $5.535 \mathrm{KWh} / \mathrm{m} 2$ per day. The vast Sahel Savanna expanse they add, provides a massive land space for a solar project, which if adequately covered with Solar PV Panels at an approximate 3000 kilometer radius will yield 6000 Mega Watts of power - which is more than the nation's current on-grid capacity. They also propose an off grid option were one million homes in Nigeria can be equipped with a $1000 \mathrm{~W}$ solar power system on their rooftops, meaning a total power production output of 7000MW, which is close to the Vision 30:30:30 - 9000MW renewable energy target. This is also a good leapfrogging option considering the poor state of the Country's on-grid transmission line and network. Although the fixing and upgrading of the transmissions lines is strategically important and is recommended by this paper, it is good to take into consideration the fact that the timeline for achieving this is on the medium to long term depending to a large extent on the political will of the government in power. Hence leapfrogging to the off grid roof top option will make sure the achievement of the 2030 renewable target is not affected.

Drawing from the Chinese example, the comparative analysis shows that a viable and result oriented Solar-Renewable Energy implementation is driven through Government and 
Stakeholder commitment and support. According to Zhang \& Yongxiu, 2013, Government has to drive predictable demand for Solar Power through incentives substantial enough to ensure a paradigm shift. The current dropping prices of PV technology is an opportunity that should be urgently tapped by the Nigerian Government as prices are not guaranteed to be low indefinitely. Government should create a stable and predictable RE market through policies that are clear, concise and defined, to avoid unnecessary ambiguities that create impressions of investment risk and uncertainty - there should be a clear rule to the game, which ultimately drives investor confidence.

\section{METHODS}

This method underpinning this paper is Qualitative, considering its exploratory nature aimed at analyzing, understanding and bringing to the fore the underlying reasons behind the gap in policy formulation and implementation of solar power in Nigeria. It is also Quantitative in the sense that a survey is conducted to assess the levels of awareness, apathy and willingness to patronise RE in Nigeria, (Saunders et al, 2007).

The probability data sampling method is adopted by this paper due to limited time frame and research size respectively, and the consequent inability to access each and every element of the population for survey, (Hair et al, 2007). Notably, "the findings from the sample data can be generalised to the population with a specified degree of accuracy" - Hair et al (2007:170). The target population is not specific to any group of industry experts or persons, but since the questionnaire aims at testing the overall societal awareness, knowledge and understanding of Renewable Energy, it was open to random picks.

Hence, this paper adopts both probability and convenience sampling and in so doing, "selecting sample elements that are most readily available to participate in the study and who can provide the information required" - Hair et al (2007:181).

Each of the survey questions have been designed for a specific purpose and descriptions of intent which serves as a criteria upon which the answer and results will be interpreted.

Sixty (60) potential respondents were approached across the six geopolitical zones of the Country. Two states were randomly picked per region with 5 questionnaire administered per state, making it 10 questionnaires per region. The States picked were Abia and Enugu for the South East, Plateau and Benue for the North Central, Edo and Rivers for South South, Lagos and Ondo for South West, Sokoto and Kebbi for North West and Adamawa and Bauchi for North East. Please see appendix for questionnaire.

Relevant Energy journals, articles, papers, databases and websites are explored in coming up with review, analysis, conclusions, and recommendations. The integrity of these sources were well verified considering the constructive critique and solutions the report is meant to proffer. Primary data as earlier highlighted was gathered via questionnaire survey. For secondary data, literature examining critical issues that influence the gap in policy formulation, implementation and solar renewable energy delivery were accessed. Literature providing rare insights, knowledge, solutions and sensitizations on the Renewable industry as a whole were also accessed.

A comparative analysis was done to highlight strategic steps taken by contemporary and specifically chosen Countries, in attaining their Solar RE success so far, and in so doing this paper attempts at leveraging these recorded successes, by applying them in the Nigerian context, as evidence for justified implementation. 
The hypothesis brought forward by this report is open for further testing and investigation in the form of an expanded Quantitative study that will incorporate research tools like interviews, (Jankowicz, 2005).

\section{SURVEY RESULTS/ANALYSIS/DISCUSSION}

Figure 1. Respondents' level of awareness and understanding of Renewable Energy, what it is and its sources?

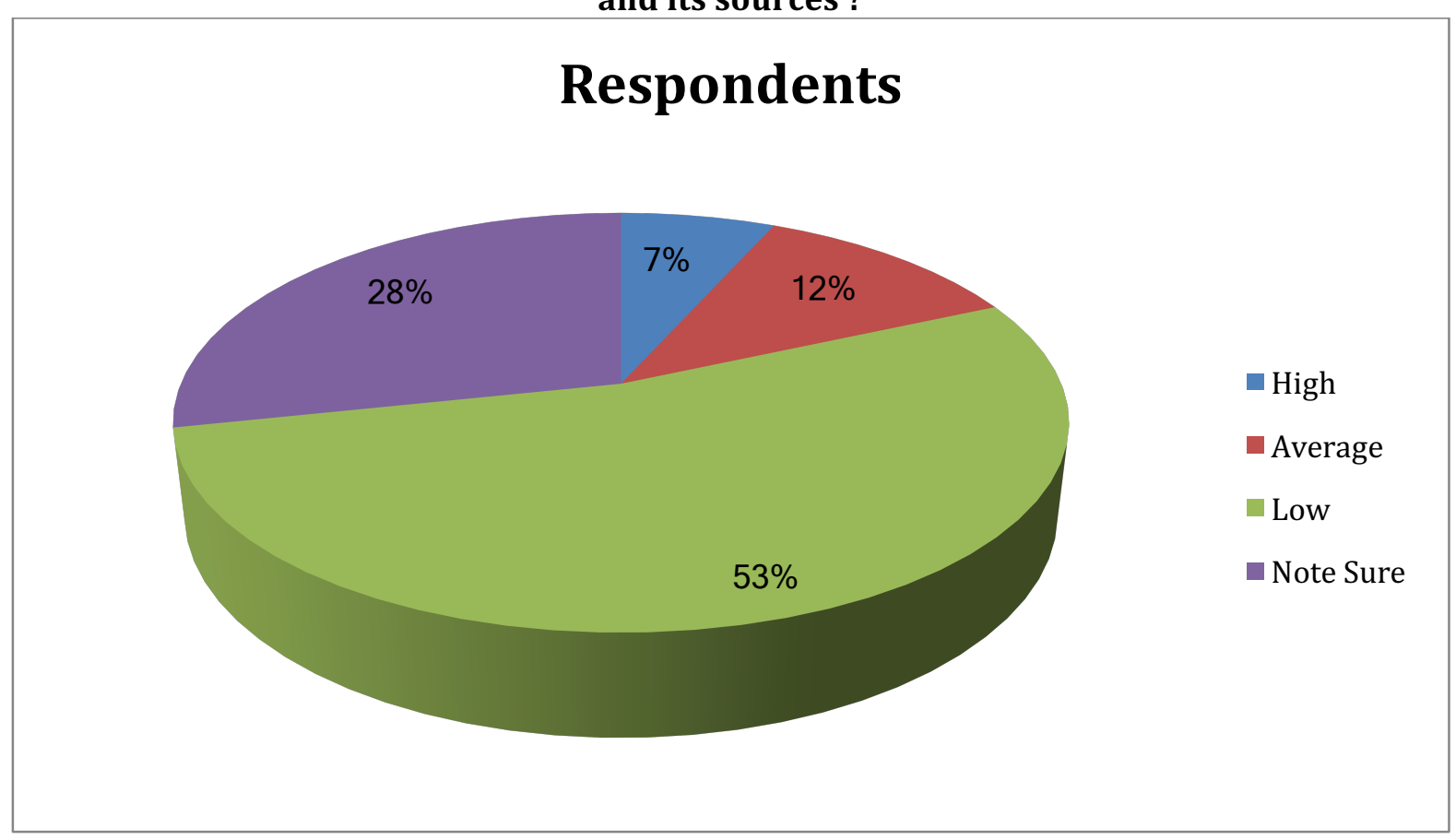

Out of 60 respondents across the six geo-political zones, who provided their feedbacks, 32 respondents representing 53\% indicated a low awareness and understanding of Renewable Energy, what it is and its sources. 17 respondents representing $28 \%$ were not sure, and that itself an indication of a seeming lack of complete awareness and understanding. 7 respondents representing 12\% indicated an average understanding and awareness, while 4 respondents representing 7\% indicated high understanding and awareness levels.

This Pie Chart indicates a very low Renewable Energy awareness and level of understanding across the Country. 
Figure 2. Societal awareness that Nigeria has abundant sources of Solar Renewable Energy which if properly harnessed, could serve as a viable and clean alternative source of Energy?

\section{Respondents}

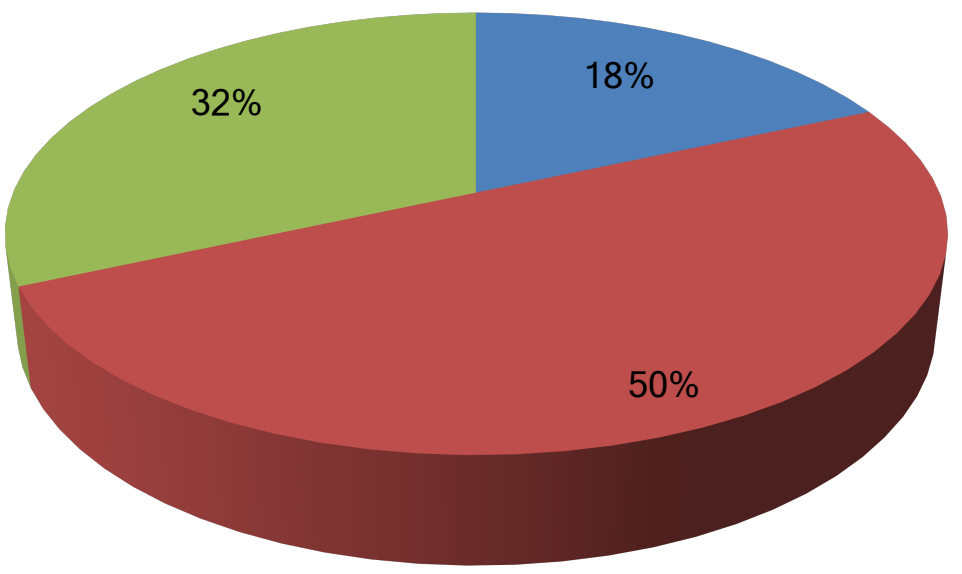

Yes

No

Not Sure

Out of 60 respondents across the six geo-political zones, 30 respondents representing 50\% were not aware of Nigeria's abundant Solar Energy potentials and the alternative benefits it presented. 19 respondents representing 32\% were not sure, and that itself an indication of a seeming lack of complete awareness. 11 respondents representing $18 \%$ indicated a good awareness of the nations abundance in Solar Energy resources

This Pie Chart indicates a reasonably high level of lack of awareness of the abundant solar energy resources present in Nigeria, and the potential benefits it brings as a clean source of alternative energy.

Figure 3. Keenness on Renewable Energy as an alternative source of Energy?

\section{Respondents}

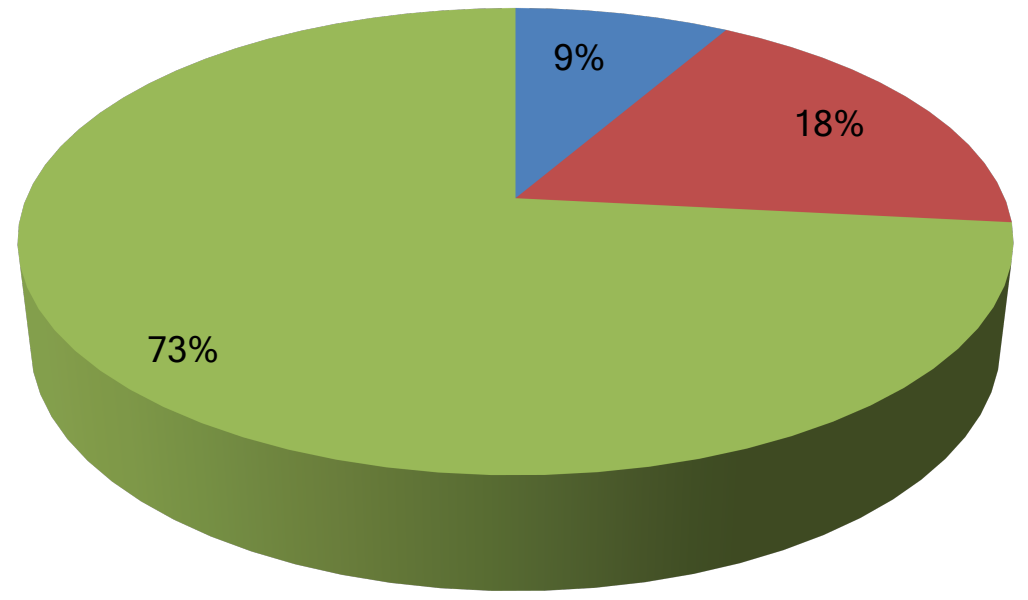

-Yes

No

Not Sure 
Out of the 60 respondents across the six geo-political zones who provided their feedbacks, 44 respondents representing $73 \%$ indicated they were not sure as to whether they were keen on the viability of Renewable Energy as an alternative source of energy. 11 respondents representing $18 \%$ categorically said no - an indication of a seeming lack of complete understanding or appreciation. 5 respondents representing $9 \%$ indicated they were keen, it can be interpreted to mean they were aware, hence understood and appreciated the complementary benefits Renewable Energy brings to the mix.

This Pie Chart indicates a very low level of keenness towards Renewable Energy in Nigeria by citizens, this is basically due to lack of availability of the requisite information, knowledge and sensitization needed by the citizens to appreciate it for what it is, its sources and benefits.

Figure 4. Would you be keen on Renewable Energy, if you were fully informed or aware of its energy-poverty alleviation potentials, its being a viable and cost friendly alternative to providing stable electric power supply?

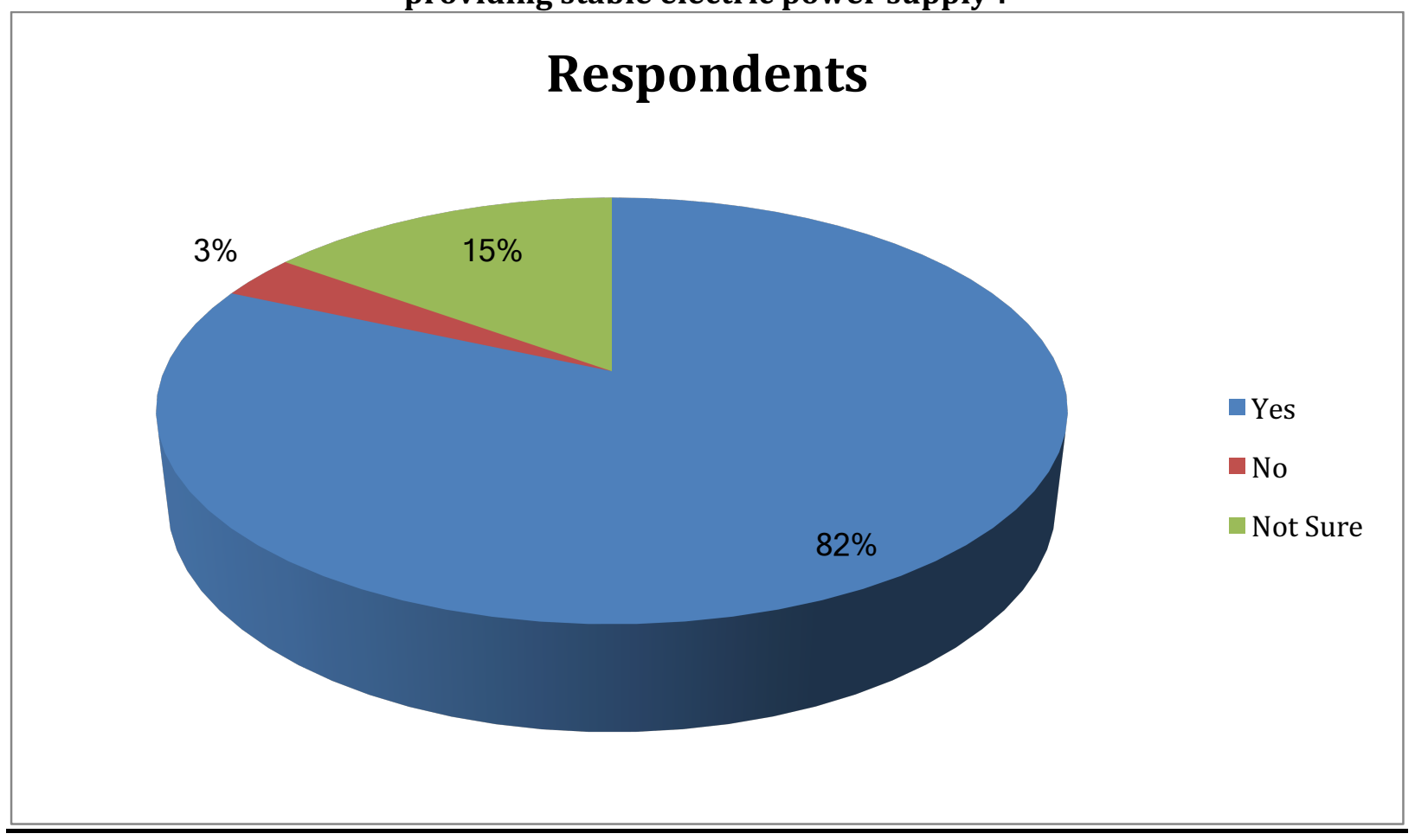

Out of the 60 respondents who provided their feedbacks, 49 respondents representing $82 \%$ indicated they will be keen on Renewable Energy if they had prior information detailing the energy-poverty alleviation potentials of Renewable Energy. 2 respondents representing 3\% said no and they will still not be keen on Renewable Energy despite being availed of necessary details and information. 9 respondents representing $15 \%$ were still not sure if the will be keen despite detailed information been provided.

This Pie Chart indicates a high willingness by Nigerians to patronise Renewable Energy, if they were adequately sensitized, informed or educated on its potentials and benefits. 
Figure 5. Have you come across any Government information defining Renewable Energy, its sources and benefits?

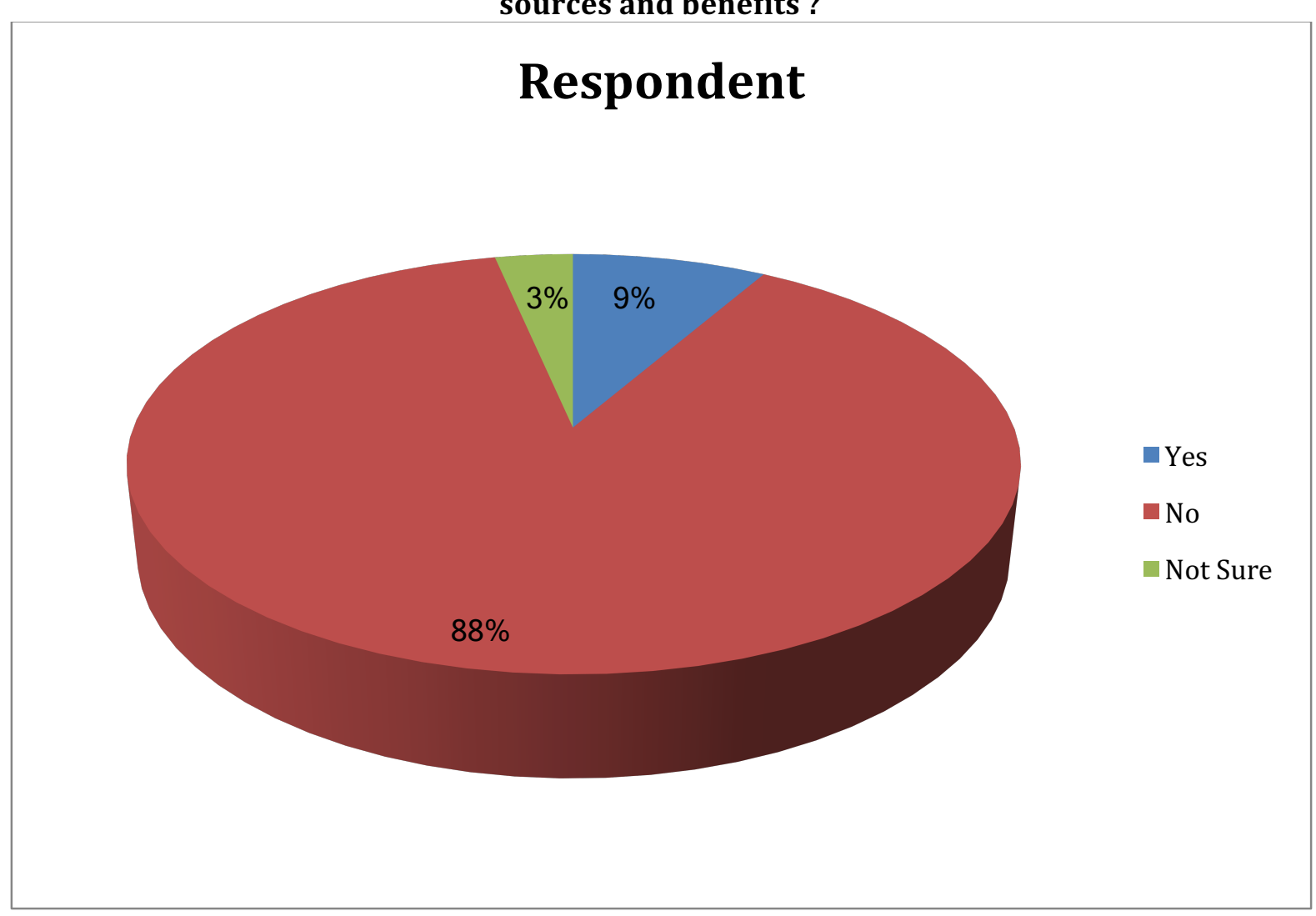

Out of the 60 respondents who provided their feedbacks, 53 respondents representing 88\% indicated they had not come across any Government backed or inspired information explaining or defining Renewable Energy in all its ramifications for the benefit of Nigerians. 5 respondents representing 9\% said yes, they had received or seen Government backed information explaining Renewable Energy. 2 respondents representing 3\% were not sure if they ever came across any such information.

This Pie Chart indicates a very low or poor level of information dissemination/communication on Renewable Energy, towards Nigerians from Government. 
Figure 6. Would you be keen on an alternative source of energy that never depletes, nor is harmful to the environment, and is potentially bound to be lower in costs overtime.

\section{Respondents}

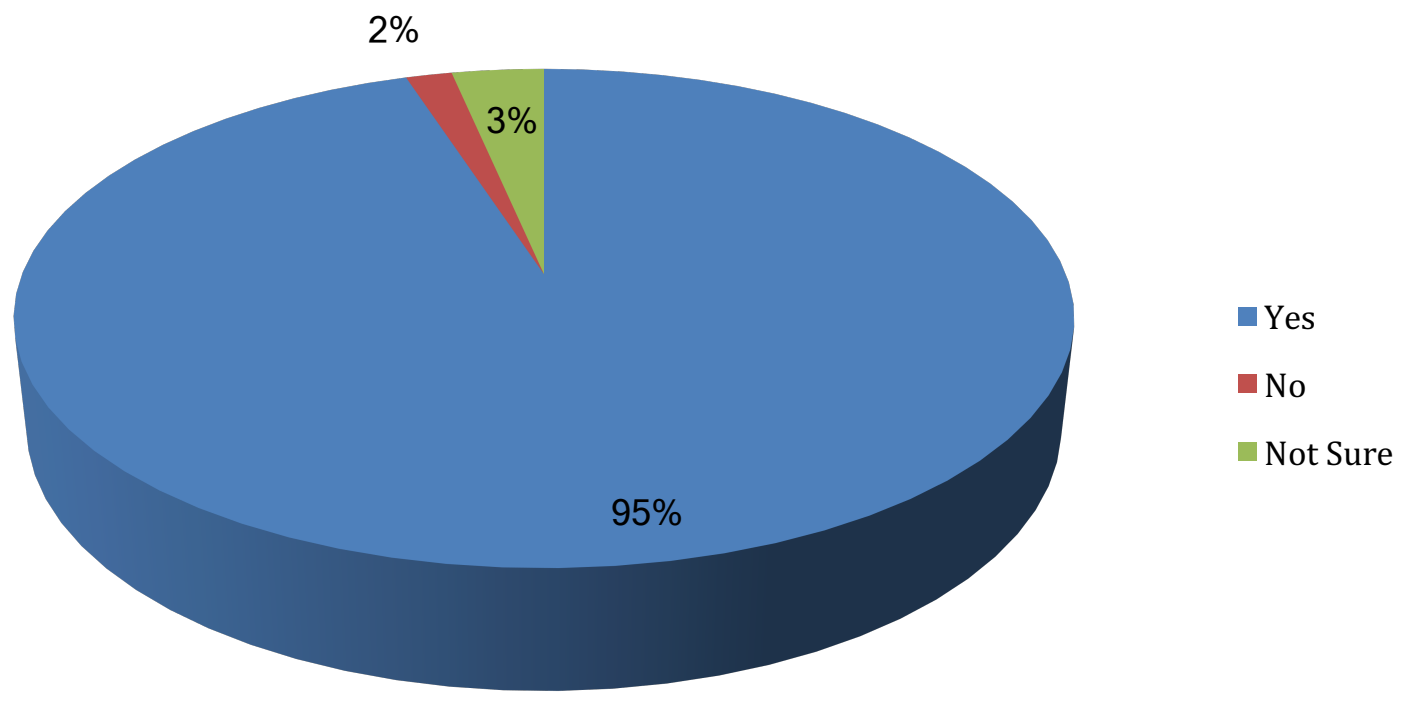

This specific survey question was designed to speak for itself, and understood easily without any prior knowledge pertaining to Renewable Energy or the technicalities involved.

Out of the 60 respondents who provided their feedbacks, 57 respondents representing 95\% indicated, based on this specific question, they will opt for this alternative source of energy with its stated benefits. 1 respondent representing $2 \%$ said no, while 2 respondents representing 3\% indicated not being sure if they will be keen on this alternative energy source..

This Pie Chart indicates a willingness to patronise or utilise clean energy and exploit all its benefits by a majority of respondents, and in extension Nigerians. This is despite not having the full knowledge, information or details behind Renewable Energy.

\section{STRATEGIC RECOMMENDATIONS}

1. Government through the National Orientation Agency should immediately commence s ocietal and citizen orientation, sensitisations and education on Renewable Energy in all its ramifications. Emphasis should be placed on enlightenment as to what Renewable En ergy is, how it works and how it stands to benefit a country like Nigeria with abundant $\mathrm{n}$ atural sources. Platforms like the Social Media, Newspaper Adverts, TV commercials an $\mathrm{d}$ etc should be exploited in furthering this campaign.

2. Government, through the Energy Commission of Nigeria (ECN), National Orientation Ag ency (NOA), in collaboration with Renewable Energy Association of Nigeria (REAN), sho uld facilitate a seamless communication of the Vision 30:30:30 policy to Nigerians in the form of nationwide sensitizations, seminars, outreaches and inclusive conferences.

3. Government, through the Bank of Industry (BOI), in partnership with select Commercial Banks should come up with plans to provide financial security to incentivize developers willing to invest in Solar - Renewable. This will help mitigate what the investor or devel oper will perceive to be investment risk or ROI uncertainty. Government can enter into f 
unding partnerships with banks and other lending institutions to give them the greater $\mathrm{f}$ inancial confidence needed to provide credit facilities to renewable energy developers a nd their projects.

4. Government should engender community partnerships and active participation in estab lishing Solar - Renewable Energy projects. A Private - Public Sector partnership can be s et up, under the leadership drive of the more resourceful Private Sector, to drive a com munity ownership program that empowers and puts the urban and rural communities $i$ $\mathrm{n}$ charge of the energy facilities. In so doing, they are equipped to provide maintenance, protection and operational services, that will ultimately guarantee the optimal performa nce and service delivery of these facilities, longevity of these facilities, and safety from $v$ andals, and dilapidation due to neglect.

5. Immediate mobilization of Federal and State Ministries of Education and other relevant educational stakeholders in the country, like the National Board for Technical Education and the National Universities Commission, to liaise with foreign counterparts like China , to help design technical curriculums that will aid the commencement of specific traini ng, skill acquisitions, technical competency development for Solar PV projects.

6. Increased focus on educating Government personnel and stakeholders to get them to ful ly buy into the Government Renewable Energy policy. At this point, every Government s takeholder should be fully aware of what the Vision 30:30:30 is and entails in all its ram ifications. To underline its importance, the National Institute for Policy and Strategic Stu dies, NIPSS, using its network of both international and national resource persons, can u ndertake to provide or organise educational seminars, courses and conferences aimed a t creating the needed awareness, capacity building and sensitisations.

7. The Federal Government, through its Energy subsidiaries in partnership with private ac tors and lobby groups like the Renewable Energy Association of Nigeria should liaise wi th the National Assembly to ensure a bill is sponsored, with the view to coming up with law that compels all Government agencies, Non Governmental Organizations and Privat e firms to source at least 30\% of their energy requirements from Solar - Renewables.

8. The Federal Ministry of Power should urgently allocate funds to commence immediate o verhaul, fixing and upgrade of the underperforming grid network and transmission line s. This, once completed and at optimal performance, will complement clean energy effor ts, and help bolster attempts at incorporating Solar Power into the grid for enhanced Sol ar Renewable Energy generation, evacuation and distribution.

9. The Federal Government should as a short to medium term strategy, focus on individual roof top panels to create a healthy level of independence from the grid, which largely re mains unpredictable in terms of power evacuation and distribution. This will empower both private and commercial consumers energy wise, while reducing the overall deman $\mathrm{d}$ on the grid. This can be facilitated through a roof top solar program that can start with a target of a million homes with 1000 Watts of power per home. In doing so, a realistic $t$ imeline should be set so as to ensure continuity by successive governments. The Ministr $\mathrm{y}$ of Power can draw concept from the Bangladeshi example. With a population of $163 \mathrm{~m}$ illion and increasingly soaring energy demands, Bangladesh initiated an Off Grid Solar H ome System as a leapfrogging strategy. As of mid 2016, this Solar Home program which commenced 2003, had installed over 2 million Solar Home Systems, hence providing the $m$ with Grid-independent electricity power supply. They plan to install a further 6 millio n homes by 2021 under what they term, a 'Universal Electricity Access Programme'

10. The Federal Government, through the Central Bank of Nigeria (CBN), can co-opt comme rcial banks to serve as a conduit or means through which Government financial package $\mathrm{s}$ and subsidies can be extended to enable domestic users to purchase and install roofto p panels, after which they can pay back in affordable installments deducted either from their monthly wages or periodic income. 
11. Considering the abundant Solar energy resources available to Nigeria as already highlig hted, and the potential by PV to easily convert Direct Current (DC) to Alternating Curren $t(A C)$, there is a risk that converted energy not immediately evacuated will be wasted. T his risk can be mitigated or better still fully prevented, with the aid of power storage Sol ar batteries to support energy conservation which could be critical in helping shore up $g$ rid reserves when they start working at optimal capacity. The promising news is that th e cost of battery storage facilities and technologies are fast dropping in cost globally. Th e Government and the Private Developers/Investors should proactively tap into this ena bler.

\section{CONCLUSION}

Survey results, indicate very low RE awareness across the country. Additionally, there is a predominant lack of awareness among the average Nigerian, of the abundant solar energy resources present in Nigeria, and the potential benefits it offers as an alternative source of clean energy. This partly reflects itself in the low level of keenness towards RE by Nigerians'. This is also majorly influenced by the lack of information and sensitisation needed to educate Nigerians on this global change phenomenon. It is incumbent on the Federal, State and Local Governments, to educate, sensitise, orientate Nigerians and keep them informed. Survey results indicate Nigerians are willing to patronise RE if they are adequately sensitised and educated on its potentials and benefits.

Based on the survey results, and key insight from the prior issue analysis and review, 11 strategic and practical recommendations were made that sought to tackle these issues that are central to the gaps existing between RE policy formulation and implementation in Nigeria. These recommendations if adopted and applied in practical terms, will go a long way in bridging the formulation and implementation gap currently existing.

\section{Reference}

Amankwah - Amoah, J (2014) "Solar Energy in Sub-Saharan Africa: The Challenges and Opportunities of Technical Leapfrogging". Thunderbird International Business Review. Vol. 57, No. 1.

Business Insider (2017) An entire region of China just ran on 100\% renewable energy for 7 days. Retrieved http://www.pulse.ng/bi/tech/tech-an-entire-region-of-china-just-ran-on-100-renewable-energy-for-7-daysid6907469.html

Coker, 0 (2017) "Nigeria's Renewables Market: Opportunities and Development for Solar PV. REA Consult. Hair, J.F, Money, A.H, Samouel, P and Page, M (2007) Research Methods for Business. John Wiley: England. Institute for Energy Economics and Financial Analysis (2017) China 2017 Review: World's Second-Biggest Economy Continues to Drive Global Trends in Energy Investment. Retrieved from - http://ieefa.org/wpcontent/uploads/2018/01/China-Review-2017.pdf

Independent Energy Watch Initiative (2016) President Buhari outlines Nigeria's plans on clean energy. Retrieved from - http://iwin.org.ng/index.php/news/item/4779-president-buhari-outlines-nigeria-s-plans-on-clean-energy

International Energy Agency (2014) How solar energy could be the largest source of electricity by mid-century. Retrieved from - https://www.iea.org/newsroom/news/2014/september/how-solar-energy-could-be-thelargest-source-of-electricity-by-mid-century.html

International Renewable Energy Agency (2017) Boosting Solar PV Markets: The Role of Quality Infrastructure. Retrieved from -

http://www.irena.org/DocumentDownloads/Publications/IRENA_Quality_Infrastructure_for_Solar_PV_2017.pdf

Jankowicz, A.D (2005) Business Research Projects. Thomson Learning: London

Mathiesen, K (2016) 'What is holding back the growth of solar power?'. Retrieved from -

https://www.theguardian.com/sustainable-business/2016/jan/31/solar-power-what-is-holding-back-growthclean-energy 
Nigeria Electricity Hub (2016) Renewables to Drive FG's Target of 30 GW On-Grid Power Capacity by 2030. Retrieved from - http://www.nigeriaelectricityhub.com/2016/11/18/renewables-to-drive-fgs-target-of-30-gwon-grid-power-capacity-by-2030/

Nov, O.; Ye, C. (2008) 'Personality and technology acceptance: personal innovativeness in IT, openness and resistance to change'. Paper presented at the Proceedings of the Annual Hawaii International Conference on System Sciences, USA, 1 January 2008.

Okafor, E.N.C. \& Uzuegbu, J., (2010) “Challenges to Development of Renewable Energy for Electric Power Sector in Nigeria”. International Journal of Academic Research, Vol. 2., No. 2

Olaoye, T, Ajilore, T, Akinluwade, K, Omole, F \& Adetunji, A (2016) Energy Crisis in Nigeria: Need for Renewable Energy Mix. American Journal of Electrical and Electronics Engineering. Vol 4. No 1. pp 1-8

Omokaro, 0, (2008) "Energy Development in a Fossil Fuel Economy: The Nigerian Experience". The report of a National Dialogue to Promote Renewable Energy and Energy Efficiency in Nigeria. pp 55.

Osborne, M (2017) 'China's solar boom to continue through 2020 as install targets revised'. Retrieved from https://www.pv-tech.org/news/chinas-solar-boom-to-continue-through-2020-as-install-targets-revised

Project Syndicate (2017) China's Renewable Energy Revolution. Retrieved from - https://www.projectsyndicate.org/commentary/china-renewable-energy-revolution-by-jiang-kejun-and-jonathan-woetzel-2017-08

Sambo, A.S., (2009). "The Challenges of Sustainable Energy Development in Nigeria”. The Nigerian Society of Engineers Forum, Shehu Yar' Adua Centre, Abuja.

Saunders, M, Lewis, P \& Thornhill, A (2007) Research Methods for Business Students. Harlow: Pearson Education

The Nation (2015) 'Why Nigeria cannot use renewable energy'. Retrieved from -

http://thenationonlineng.net/why-nigeria-cannot-use-renewable-energy/

The Telegraph (2017) The Business Benefits of using Renewable Electricity. Retrieved from http://www.telegraph.co.uk/business/energy-efficiency/why-your-business-should-go-renewable/

The Beam Magazine (2016) Bringing solar energy to remote villages in Africa with Thomas Gottschalk. Retrieved from - https://medium.com/thebeammagazine/thomas-gottschalk-859863f72abd

The Telegraph (2017) Why off-grid power appeals to larger energy users. Retrieved from http://www.telegraph.co.uk/business/energy-efficiency/off-grid-power-for-large-businesses/

Vorrath, S (2017) 'China set to add another 50GW new Solar PV in 2017'. Retrieved from http://reneweconomy.com.au/china-set-add-50gw-new-solar-pv-2017/

World Bank (2017) Making Renewable Energy More Accessible in Sub-Saharan Africa. World Bank.

Wixom, B.H.; Todd, P.A. (2005) 'A theoretical integration of user satisfaction and technology acceptance'. Information Systems Research. Vol 16, 85-102.

Wu, C.Y \& Mathews, J.A (2012) "Knowledge flows in the solar photo-voltaic industry: Insights from patenting by Taiwan, Korea and China. Research Policy". Vol. 41, 524 - 540.

Zhang, S \& Yongxiu He (2013) 'Analysis on the development and policy of solar PV power in China'. Renewable and Sustainable Energy Reviews. Vol 21.393-401.

\section{APPENDIX}

\section{A QUESTIONNAIRE/SURVEY ASSESSING THE UNDERSTANDING AND AWARENESS LEVELS OF RENEWABLE ENERGY IN NIGERIA}

You are kindly invited to participate in this very short survey investigating the awareness, level of understanding and probable apathy towards Renewable Energy in Nigeria. This research in seeking your response, intends to assess and better understand what may be a major causative factor impeding the holistic implementation of Renewable Energy policies, projects, and harnessing of its abundant resources in Nigeria.

All information provided will be used for academic/research purposes only and in strict confidential terms without any form of disclosure of personal information or identity to any 
third parties. As can be seen below, you are not obliged to disclose your name or any other personal details.

Survey feedback will be analysed, interpreted and presented in a simplified pie chart.

(1) How would you describe your level of awareness and understanding of Renewable Energy, what it is and its sources?

High ()

Average ()

Low ()

Not Sure ( )

(2) Are you aware Nigeria has abundant sources of Solar Renewable Energy which if properly harnessed, could serve as a viable and clean alternative source of Energy?

Yes ( )

No ()

Not Sure ( )

(3) Would you say at this point, you are keen on Renewable Energy as an alternative source of Energy?

Yes ( )

No ()

Not Sure ( ) Apathy

(4) Would your answer to number 3 above been different if you were fully aware of Renewable Energy, its energy-poverty alleviation potentials, its being a viable and cost friendly alternative to providing stable electric power supply?

Yes ( )

No ()

Not Sure ( )

(5) Have you come across any Government information defining Renewable Energy, its sources and benefits?

Yes ( )

No ()

Not Sure ( )

(6) Would you be keen on an alternative source of energy that never depletes, nor is harmful to the environment, and is potentially bound to be lower in costs overtime.

Yes ()

No ()

Not Sure ( ) 